\title{
Unusual behaviour of serological tests for syphilis in Ugandan Africans
}

\author{
AARON E. J. MASAWE* ${ }_{+}^{+}$, GUNNAR LOMHOLT*, KIMMO AHO \\ AND ALLAN LASSUS† \\ From the ${ }^{\star}$ Department of Medicine, Makarere University, Kampala, Uganda, and the \\ †State Serum Institute, Helsinki, Finland
}

The fluorescent treponemal antibody (FTA) test developed by Deacon, Falcone, and Harris (1957) and later modified with the absorption procedure by Hunter, Deacon, and Meyer (1964) has contributed much to the better diagnosis and control of syphilis in many parts of the world (WHO Scientific Group Report, 1970). The test combines the sensitivity and specificity of immunofluorescence with easy reproducibility (Mora, 1969) and is now the most popular treponema! test for syphilis (Sparling, 1971). Compared with other serological tests, it is highly sensitive at all stages of the disease (Atwood, Miller, Stout, and Norins, 1968; Garner, Grantham, Collins, and Roeder, 1968; Knox, Short, Wende, and Glicksman, 1966; Lassus, Mustakallio, Aho, and Putkonen, 1967) and nearly equals the Treponema pallidum immobilization test in specificity (Deacon, Lucas, and Price, 1966; Garner and others, 1968; Goldman and Lantz, 1971).

In Uganda and probably the whole of tropical Africa, the FTA-ABS test is not yet available. Reagin screening tests, either the VDRL slide test or the PPR, and the RPCF test for confirmation of treponemal antibodies, are the only tests available. They are cheap and easy to perform, but are not very specific and are less sensitive in late or inadequately treated cases of syphilis (Gillespie and Brown, 1964; Nicholas and Beerman, 1965; Sparling, 1971).

This communication reports a comparative assessment of the FTA-ABS, RPCF, Kolmer, and VDRL slide tests in 402 indigenous African subjects with verified or suspected syphilis or miscellaneous conditions. In addition, 163 controls were tested with the FTA-ABS, TPI, and VDRL slide tests.

Received for publication May 16, 1971

Address for correspondence: Allan Lassus, M.D., Department of Dermatology and Venereology, University Central Hospital, Helsinki, Snellmaninkatu 14, 00170 Helsinki 17, Finland

$\ddagger$ Present address: Department of Medicine, University of Dar es Salaam, Tanzania

\section{Material and methods}

Serum specimens from the following categories of subjects were studied:

(a) 129 with darkfield-positive primary syphilis, 90 with darkfield-positive secondary syphilis, and 99 with genital sores (darkfield negative), all diagnosed at the VD clinic of Mulago Hospital, Makarere University, Kampala. The patients with secondary syphilis had typical rashes and/or lymphadenopathy and positive serum was obtained for darkfield examination from genital, oral, or other lesions.

(b) Five children with congenital syphilis diagnosed clinically, serologically (PPR and RPCF tests), and/or radiologically at the Paediatric Unit of Mulago Hospital.

(c) Eight subjects with definite or suspected latent syphilis (diagnosed after having given birth to a baby with congenital syphilis or after having yielded positive PPR and RPCF tests in routine screening for blood transfusion).

(d) Forty patients with parenchymatous neurosyphilis admitted to Butabika Mental Hospital and diagnosed as having general paralysis of the insane (GPI) by criteria reported elsewhere (Masawe and German, in press). Only six of these cases were known to have been previously treated.

(e) Thirty-one subjects with miscellaneous conditions randomly selected from the out-patients of Mulago Hospital.

(f) Thirty-nine secondary school students, 81 paediatric patients, and 43 convicts, randomly selected, were tested at a later stage of the investigation.

\section{Serum processing}

10 to $20 \mathrm{ml}$. of blood were withdrawn by venepuncture from each subject, placed in an ice box at $4^{\circ} \mathrm{C}$. until the serum separated, centrifuged at the same temperature, quickly pipetted into clean plastic containers, and stored at $-20^{\circ} \mathrm{C}$. until they were shipped to Helsinki for evaluation. None was stored for more than 1 year before analysis. They were transported by air in dry ice boxes.

\section{Serum testing}

At the State Serum Institute, Helsinki, the following serological tests for syphilis were performed: 
(i) The VDRL slide test was carried out according to the standard procedures outlined in the U.S. 'Manual of Tests for Syphilis' (USPHS, 1969) using Bacto VDRL antigen.

(ii) The Kolmer complement-fixation test was performed by mixing $0.1 \mathrm{ml}$. of serum dilution, Bacto Kolmer cardiolipin antigen, and complement dilution (corresponding to two full units), incubating the mixture overnight at $4^{\circ} \mathrm{C}$., and adding $0.2 \mathrm{ml}$. sensitized sheep red cells.

(iii) The Reiter protein complement-fixation test was performed essentially like the Kolmer test, but smaller volumes and microlitre plates were used. The antigen was obtained from BD Merieux, Lyon, France.

(iv) The FTA-ABS test was carried out as described in the U.S. 'Manual of Tests for Syphilis' (USPHS, 1969). The antigen and the sorbent were purchased from Difco; the fluorescent antihuman globulin was made locally in Helsinki and recognized IgG and IgM immunoglobulins. Finally the reactions were visualized by a Leitz-Orthoplan microscope.

(v) The TPI test was performed as described by Lassus (1968).

All the initial determinations for the VDRL slide, Kolmer, and RPCF tests were carried out at serum dilutions of $1: 4$ corresponding in reactivity to one dilution in the complement-fixation tests. If, however, the VRDL slide test was negative at this dilution, the test was repeated using a $1: 2$ dilution and undiluted serum. The dilution series for the three tests were made in bulk.

Categories $a$ to $e$ were tested with the VDRL slide, Kolmer, RPCF, and FTA-ABS tests; category $f$ was tested with the VDRL slide, FTA-ABS, and TPI tests.

\section{Results}

The patients with primary, secondary, and latent syphilis were young, their mean ages being 24, 23, and 27 years respectively. The mean age of the patients with tertiary syphilis was 45 years, and they had contracted the disease 21 years earlier on an average. The mean age of the patients with congenital syphilis was 5 months.

There were more males than females, partly because the VD clinic from which most of the patients were drawn served mainly males and their female contacts during the period of study. A clinic for females was started a few months after the study. For example, among the patients with primary syphilis, there were fifteen males to one female, among those with secondary syphilis eight males to five females, and among those with tertiary syphilis seven males to one female.

The serological findings are summarized in Tables I, II, and III. The FTA-ABS was the most sensitive test for syphilis; it was reactive in 89.9 per cent. of cases of primary syphilis ( 86.0 per cent. definite and 3.9 per cent. borderline), and in 100 per cent. of cases of GPI ( 97.5 per cent. definite and 2.5 per cent. borderline). In the other stages of syphilis the test was 100 per cent. reactive. Among patients with genital sores and miscellaneous conditions, the FTA-ABS test was also more often reactive than the other tests.

Of the 402 specimens of categories $a$ to $e, 23$ $(5.7$ per cent.) showed borderline reactivity to the FTA-ABS test. Nineteen of these were VDRL slide test negative, fifteen RPCF test negative, and nineteen Kolmer test negative.

The RPCF was less reactive than the FTA-ABS test, particularly in cases of secondary syphilis, only 86.7 per cent. being reactive to it. 29 patients $(7 \cdot 2$ per cent. of the 402) had anti-complementary reactions; twenty of these were FTA-ABS test positive and three gave borderline reactions to the FTA-ABS test.

TABLE I Percentage distribution of positive results in the serological tests for syphilis in 402 patients

\begin{tabular}{|c|c|c|c|c|c|c|c|c|c|}
\hline \multicolumn{3}{|c|}{ Diagnosis } & \multicolumn{5}{|l|}{ Syphilis } & \multirow{3}{*}{$\begin{array}{l}\begin{array}{l}\text { Genital } \\
\text { Sores }\end{array} \\
36 \cdot 4 \\
12 \cdot 1\end{array}$} & \multirow{3}{*}{$\begin{array}{l}\begin{array}{l}\text { Miscellaneous } \\
\text { conditions }\end{array} \\
21 \cdot 4 \\
17 \cdot 9\end{array}$} \\
\hline & & & \multirow{2}{*}{$\begin{array}{c}\text { Primary } \\
86.0 \\
3.9\end{array}$} & \multirow{2}{*}{$\begin{array}{l}\text { Secondary } \\
100 \\
-\end{array}$} & \multirow{2}{*}{$\begin{array}{l}\text { Latent } \\
100 \\
-\end{array}$} & \multirow{2}{*}{$\frac{\text { Congenital }}{100}$} & \multirow{2}{*}{$\begin{array}{r}G P I \\
97 \cdot 5 \\
2 \cdot 5\end{array}$} & & \\
\hline Test & FTA-ABS & $\begin{array}{l}+ \\
\pm\end{array}$ & & & & & & & \\
\hline & RPCF & $\stackrel{+}{A C}$ & $\begin{array}{r}71 \cdot 3 \\
4 \cdot 7\end{array}$ & $\begin{array}{r}86 \cdot 7 \\
6 \cdot 7\end{array}$ & $\begin{array}{l}62.5 \\
12.5\end{array}$ & $\begin{array}{l}60 \cdot 0 \\
40 \cdot 0\end{array}$ & $\begin{array}{r}67 \cdot 5 \\
5 \cdot 0\end{array}$ & $\begin{array}{r}27 \cdot 3 \\
9 \cdot 1\end{array}$ & $\begin{array}{r}10 \cdot 7 \\
3.6\end{array}$ \\
\hline & $\begin{array}{l}\text { VDRL } \\
\text { slide }\end{array}$ & + & $63 \cdot 6$ & $96 \cdot 7$ & $87 \cdot 5$ & $80 \cdot 0$ & $52 \cdot 5$ & $22 \cdot 2$ & $10 \cdot 7$ \\
\hline & Kolmer & $\stackrel{+}{A C}$ & $\begin{array}{r}67 \cdot 4 \\
3 \cdot 1\end{array}$ & $\begin{array}{r}94 \cdot 4 \\
4 \cdot 4\end{array}$ & $\begin{array}{l}87 \cdot 5 \\
-\end{array}$ & $\begin{array}{l}80 \cdot 0 \\
20 \cdot 0\end{array}$ & $\begin{array}{l}60 \cdot 0 \\
10 \cdot 0\end{array}$ & $\begin{array}{r}28 \cdot 3 \\
2 \cdot 0\end{array}$ & $\begin{array}{r}14.3 \\
3.6\end{array}$ \\
\hline \multicolumn{3}{|c|}{ Total no. of patients } & 129 & 90 & 8 & 5 & 40 & 99 & 31 \\
\hline
\end{tabular}


TABLE II Comparison of the FTA-ABS test with the other serological tests in 402 patients

\begin{tabular}{|c|c|c|c|c|c|c|c|c|c|}
\hline \multirow[b]{2}{*}{$F T A-A B S$ test } & \multicolumn{3}{|c|}{ VDRL slide test } & \multicolumn{3}{|c|}{ Kolmer test } & \multicolumn{3}{|c|}{$R P C F$ test } \\
\hline & + & \pm & - & + & $A C$ & - & + & $A C$ & - \\
\hline $\begin{array}{l}+(295) \\
\pm(23) \\
-(84)\end{array}$ & $\begin{array}{r}213 \\
3 \\
3\end{array}$ & $\begin{array}{l}7 \\
1 \\
1\end{array}$ & $\begin{array}{l}75 \\
19 \\
80\end{array}$ & $\begin{array}{r}230 \\
3 \\
7\end{array}$ & $\begin{array}{r}13 \\
2 \\
1\end{array}$ & $\begin{array}{l}52 \\
18 \\
76\end{array}$ & $\begin{array}{r}219 \\
5 \\
13\end{array}$ & $\begin{array}{r}20 \\
3 \\
6\end{array}$ & $\begin{array}{l}56 \\
15 \\
65\end{array}$ \\
\hline Total no. of cases & 219 & 9 & 174 & 240 & 16 & 146 & 237 & 29 & 136 \\
\hline
\end{tabular}

$t=$ reactive

$\pm=$ borderline

- = nonreactive

TABLE III Results of the FTA-ABS, TPI, and VDRL, slide tcsts in 163 control subjects

\begin{tabular}{|c|c|c|c|c|c|}
\hline \multicolumn{3}{|c|}{ Control group } & \multirow{2}{*}{$\begin{array}{l}\begin{array}{l}\text { Paediatric } \\
\text { patients }\end{array} \\
\overline{1}\end{array}$} & \multirow{2}{*}{$\begin{array}{l}\text { High school } \\
\text { students }\end{array}$} & \multirow{2}{*}{$\begin{array}{c}\text { Convicts } \\
10 \\
2\end{array}$} \\
\hline Test & FTA-ABS & $\begin{array}{l}\therefore \\
\pm\end{array}$ & & & \\
\hline & TPI & + & - & 1 & 8 \\
\hline & $\begin{array}{l}\text { VDRL } \\
\text { slide }\end{array}$ & \pm & $\bar{z}$ & $\overline{1}$ & $\begin{array}{l}4 \\
3\end{array}$ \\
\hline \multicolumn{3}{|c|}{ Total no. of subjects } & 81 & 39 & 43 \\
\hline
\end{tabular}

The VDRL slide test was the least reactive, especially in cases of primary and tertiary syphilis, in which it was positive in 63.6 and 52.5 per cent. respectively. Nine patients had borderline reactions and seven of these were positive to the FTA-ABS test. In terms of titres, 63 per cent. of cases with primary syphilis, 12 per cent. of those with secondary syphilis, and 73 per cent. of those with GPI were reactive at titres of $1: 4$ or less.

The Kolmer test was similar to the VDRL slide test in reactivity, but was generally more sensitive. As with the RPCF test, anticomplementary reactions were found in sixteen cases ( 3.9 per cent. of the 402$)$; thirteen of these sixteen cases were FTA-ABS test positive and two showed borderline reactions to the FTA-ABS test.

The number of negative results with the RPCF, VDRL slide, and Kolmer tests was remarkably high (Table II). Only 84 cases were FTA-ABS negative, but 174 were VDRL, slide test negative, 146 were Kolmer test negative, and 136 were RPCF test negative. Considering the 295 cases reactive to the FTA-ABS test, 75 were VDRL slide test negative, 52 Kolmer test negative, and 56 RPCF test negative.

Table III illustrates the serological findings in category $f$.

One secondary school student had a positive FTA-ABS and TPI test and a borderline result in the VDRL slide test; one paediatric patient had a borderline result in the FTA-ABS test, and all the other 118 children were seronegative in all three tests.

Twelve of the 43 convicts had either a positive or borderline result in the FTA-ABS test and seven of these also had a positive TPI test. In one case the TPI test was reactive, while the FTA-ABS test was non-reactive. The VDRL slide test was reactive in four cases and borderline in three; the FTA-ABS test was reactive in all seven cases.

\section{Discussion}

The value of a serological test depends on its sensitivity (ability to react in the presence of disease), specificity (inability to react in the absence of disease), and reproducibility. In syphilology today, the FTA-ABS test is the most sensitive test available (Mora, 1969). It becomes reactive early in primary syphilis (Deacon and others, 1966; Garner and others, 1968; Lassus, and others, 1967; Sparling, 1971), and remains positive for many years in long-standing syphilis even after apparently adequate therapy (Atwood and others, 1968; Knox and others, 1966; Lassus, 1968; Rockwell, Yobs, and Moore 1964). In terms of specificity it nearly equals the TPI test. Occasional false positive results have been reported, but rarely in more than 1 per cent. of cases (Sparling, 1971).

In the present study, the FTA-ABS test was the 
most sensitive of the tests used. It was reactive in all cases of secondary, latent, and congenital syphilis, and in all except one case of GPI (which showed a borderline reaction). Most patients with primary syphilis also had reactive FTA-ABS tests, but at this stage the seroreactivity is largely dependent on the duration of the infection (Lassus and others, 1967). Two patients with primary syphilis who had non-reactive FTA-ABS tests, had reactive VDRL slide tests; this suggests that occasionally reagin antibodies may develop earlier than treponemal antibodies. A few patients with primary syphilis also had a borderline FTA-ABS test result. However, the significance of borderline reactions to the FTA-ABS test is questionable ('Syphilis: a Synopsis', USPHS, 1968).

By contrast, the other tests (VDRL, Kolmer, and RPCF) are less sensitive and less specific (Gillespie and Brown, 1964; Nicholas and Beerman, 1965 Sparling, 1971). In countless conditions, both acute and chronic, the reagin tests react non-specifically (Gillespie and Brown, 1964; Nicholas and Beerman, $1965)$; in 30 to 40 per cent. of late and inadequately treated cases of syphilis, these tests do not react at all (Gillespie and Brown, 1964; Nicholas and Beerman, 1965; Sparling, 1971). In the present study, the latter phenomenon was even more marked. In the VDRL slide test for example, 3.3 per cent. of cases with secondary syphilis and almost half of those with GPI were non-reactive. In terms of titres, over 70 per cent. of cases of GPI, over 60 per cent. of cases of primary syphilis, and over 10 per cent. of cases of secondary syphilis were reactive at $1: 4$ or less. The low VDRL slide titres in some cases of secondary syphilis is of special interest. Using the same system of tests, it could be shown that only one out of 69 Finnish patients with secondary syphilis had a VDRL slide titre as low as $1: 4$ (Lassus, unpublished data).

The reason for this very unusual finding of seronegativity is far from clear. Faulty technique is by no means the explanation. Every precautionary measure was taken throughout the study to ensure that all conceivable sources of error were checked. In addition, our results are comparable with those in 75 patients with secondary syphilis tested at Kampala: eight (10 per cent.) were non-reactive to the PPR test and nine (12 per cent.) to the RPCF test (Masawe, 1970).

The treponemal tests do not differentiate venereal from endemic syphilis. The fact that endemic treponematoses were prevalent in Uganda until about 1949 to 1950 (Masawe, 1970, 1971) may explain some of the positive FTA-ABS results in the adult control groups. On the other hand, the school children and paediatric patients showed a low degree of seroreactivity, suggesting that both congenital syphilis and endemic treponematoses are now not very frequent in Uganda.

Antibiotics dispensed for conditions other than syphilis suppress syphilitic antibodies (Gillespie and Brown, 1964). After penicillin therapy antilipoidal antibodies disappear within 6 to 12 months in primary syphilis and within 12 to 18 months in secondary syphilis (USPHS, 1968). Because antibiotics are frequently and liberally dispensed in Uganda, it is possible that these had altered the levels of antibodies in some of our patients. However, this cannot account for the false negative results in cases of secondary syphilis.

Whatever the explanation, it must be noted that the VDRL slide screening test and the RPCF confirmatory test are the only tests for syphilis available in Uganda (Masawe, 1970). With a margin of false negative results as wide as in this study, it means that numerous cases of syphilis escape diagnosis during the screening and confirmatory stages of serological testing. Cohen, Stout, and Ende (1969) studied 468 consecutive patients with a high incidence of venereal disease admitted to a hospital and showed that about 50 per cent. of the FTA-ABS reactors were not detected by the VDRL slide test. In Kampala, Masawe (1970), reviewing all the serological tests carried out at the Mulago Central Laboratory, showed that over 30 per cent. of reagin-positive sera which are passed on for confirmation by the RPCF test do not react to the latter.

Syphilis is highly prevalent in certain sectors of the population in Uganda; about 2000 to 3000 new cases of primary and secondary syphilis are diagnosed and treated each year at the VD clinic, Mulago; about 1 to 3 per cent. of new admissions to Butabika Mental Hospital, Kampala, are diagnosed as cases of GPI (Masawe and German, 1972); about 4 to 6 per cent. of cases at the Cardiac Clinic, New Mulago Hospital, have cardiovascular syphilis (Masawe, 1970); over thirty new cases of congenital syphilis are diagnosed and treated at the paediatric unit, New Mulago Hospital, annually (Masawe, 1970); over 21 per cent. of unselected subjects are reactive to the FTA-ABS test. It must therefore be concluded that the VDRL slide screening test and the RPCF confirmatory test are inadequate and unreliable for use in any campaign against syphilis in this country.

\section{Summary}

Sera from 402 indigenous African subjects with various forms of syphilis, darkfield-negative genital sores, and miscellaneous conditions were tested for syphilis by the FTA-ABS, RPCF, VDRL slide, and 
Kolmer tests. In addition, a total of 163 school children, paediatric patients, and convicts was tested with the FTA-ABS, TPI, and VDRL slide tests.

The FTA-ABS test was by far the most sensitive; it was reactive in 86 per cent. of 129 patients with primary syphilis, in all those with secondary, latent, and congenital syphilis, in 97.5 per cent. of those with tertiary syphilis, and in 36 per cent. of the 99 patients with genital sores. The other tests were less sensitive and yielded many false negative results, especially in cases of GPI. Of the patients with secondary syphilis 12 per cent. had negative results in the VDRL slide test or showed only very low titres. The possible reasons for this unusual finding are discussed. The percentage of seroreactivity in children was low, indicating a high degree of specificity in the FTA-ABS test in this tropical area, while the rate of seroreactivity among the adult controls was high, especially in the FTA-ABS test.

Our thanks are due to the staff of the VD Clinic, Mulago, and of the Butabika Hospital for their cooperation and assistance. The project was supported by the Danish Government, the Uganda Government, Makarere University Research Grant 620, and the Sigrid Juselius Foundation.

\section{References}

Atwood, W. G., Miller, J. L., Stout, G. W. and Norins, L. C. (1968) f. Amer. med. Ass., 203, 549

Cohen, P., Stout, G., and Ende, N. (1969) Arch. intern. Med., 124, 364

Deacon, W. E., Falcone, W. H., and Harris, A. (1957) Proc. Soc. exp. Biol. (N.Y.), 96, 477

- LuCas, J. B., and Price, E. V. (1966) F. Amer. med. Ass., 198, 624

Garner, M. F., Grantham, N. M., Collins, C. A., and Roeder, P. J. (1968) Med. F.. Aust., 1, 404

Gillespie, E. J., and Brown, B. C. (1964) Med. Clin. N. Amer., 48, 731

Goldman, J. N., and Lantz, M. A. (1971) f. Amer. med. Ass., 217, 53

Hunter, E. F., Deacon, W. E., and Meyer, P. E. (1964) Publ. Hlth Rep. (Wash.), 79, 410

Knox, J. M., SHORT, D. H., Wende, R. D., and GlicksMAN, J. M. (1966) Brit. F. vener. Dis., 42, 16

LAssus, A. (1968) Acta derm.-venereol. (Stockh.), 48, Suppl. 60
- Mustakallio, K. K., Aho, K., and Putkonen, T. (1967) Acta path. microbiol. scandin. 69, 159

Masawe, A. E. J. (1970) East Afr. med. F., 47, 673

- (1971) 'Syphilis in Uganda. History, Clinical Features, and Cellular Immunity'. A thesis for $M$. Med., Makarere Univeristy

- and German, A. G. (1972) Afr. F. med. Sci., 3, 195

MORA, Z. P. (1969) Brit. F. vener. Dis., 45, 23

Nicholas, L., and Beerman, H. (1965) Amer. F. med. Sci. 249, 466

Rockwell, D. H., Yobs, A. R., and Moore, M. B., Jr. (1964) Arch. intern. Med., 114, 792

Sparling, P. F. (1971) New Engl. F. Med., 284, 642

United States Department of Health, Education AND WeLfare (1968) 'Serologic interpretation' in 'Syphilis: A Synopsis', p. 96. Public Health Service Publication No. 1660

(1969) 'Manual of Tests for Syphilis' Public Health Service Publication No. 411. U.S. Government Printing Office, Washington, D.C.

WHO SCIENTIFIC GROUP REPORT (1970) 'Treponematoses Research', W.H.O. Tech. Rep. Ser. 455

\section{Comportèment inhabituel des tests sérologiques pour la syphilis chez des Africains de l'Ouganda}

\section{SOMMAIRE}

Les sérums de 402 indigènes africains présentant différentes formes de syphilis, des plaies génitales négatives au fond noir et des maladies diverses, furent testés pour la syphilis par le FTA-ABS, le RPCF, le VDRL sur lame et le Kolmer. En outre, 163 écoliers, des malades de pédiâtrie et des prisonniers furent examinés par le FTA-ABS, le TPI et le VDRL sur lame.

Le FTA-ABS fut, de loin, la réaction la plus sensible, positive chez 86 pour cent des 129 malades atteints de syphilis primaire, chez tous ceux présentant une syphilis secondaire, latente ou congénitale, chez 97,5 pour cent des sujets avec une syphilis tertiaire et chez 36 pour cent des 99 malades atteints de plaies génitales. Les autres tests furent moins sensibles et donnèrent souvent des résultats faussement négatifs, particulièrement en cas de syphilis symptômatique tardive. 12 pour cent des malades en syphilis secondaire avaient des résultats négatifs au VDRL sur lame ou montraient seulement de très bas titres. Les raisons possibles de ces constatations inhabituelles sont discutées. Le pourcentage de positivité chez les enfants fut faible, indiquant un haut degré de spécificité du test FTA-ABS dans cette rébion tropicale, alors que le taux de positivité chez les contrôles adultes fut élevé, particulièrement pour le test FTA-ABS. 